\title{
CHEMICAL PROFILE AND ALLELOPATHIC POTENTIAL OF Anacardium humile St. Hill. (CAJUZINHO-DO-CERRADO) LEAF AQUEOUS EXTRACT IN THE SEED GERMINATION AND SEEDLING GROWTH OF LETTUCE, TOMATO AND SICKLEPOD
}

\author{
PERFIL QUÍMICO E POTENCIAL ALELOPÁTICO DO EXTRATO AQUOSO DE \\ Anacardium humile St. Hill. (CAJUZINHO-DO-CERRADO) NA GERMINAÇÃO E \\ FORMAÇÃO DE PLANTULAS DE ALFACE, TOMATE E FEDEGOSO
}

\author{
Kelly Cristina Lacerda PEREIRA ${ }^{\mathbf{1}}$; Rosemary MATIAS ${ }^{\mathbf{1}}$; Elvia Silvia RIZZI ${ }^{\mathbf{1}}$; \\ Ana Carolina ROSA ${ }^{1}$; Ademir Kleber Morbeck de OLIVEIRA ${ }^{\mathbf{1}^{*}}$ \\ 1. Graduate Studies Program in Environment and Regional Development, University Anhanguera-Uniderp, Campo Grande, MS, Brazil. \\ *akmorbeckoliveira@gmail.com
}

\begin{abstract}
Anacardium genus, Anacardiaceae, stands out for the presence of phenolic compounds. One of its species, investigated for its different potential uses, is Anacardium humile; however, little is known about its allelopathic effects. Therefore, the present study aimed to determine the chemical profile and evaluate the herbicide potential of your leaves in the germination of seeds and growth of seedlings of Lactuca sativa (lettuce), Lycopersicon esculentum (tomato) and Senna obtusifolia (sicklepod), both in vitro and in greenhouse. Leaves of A. humile were obtained from 20 matrices of Cerrado fragments in the municipality of Campo Grande, Mato Grosso do Sul state, Brazil. A voucher specimen was deposited at the herbarium (no. 8448). The aqueous extract was obtained from dried and crushed leaves using the extraction method of ultrasonic bath (30 min) with subsequent static maceration. After solvent evaporation, $12.78 \mathrm{~g}$ of extract were obtained. The chemical profile of the aqueous extract included determination of total phenolic and flavonoid contents, $\mathrm{pH}$, electrical conductivity, and soluble solids concentration. For the in vitro bioassays, the extract was used at different concentrations, namely, 25, 50, 100, 150, and $200 \mathrm{mg} \mathrm{mL}^{-1}$. In greenhouse, the substrates were prepared using $950 \mathrm{~g}$ of vermiculite and $50 \mathrm{~g}$ of $A$. humile leaf powder at the following ratios: (950/50) (5\%), $900 / 100(10 \%), 800 / 200(20 \%)$, and a control (100\% vermiculite), under a completely randomized experimental design. Phenolic compounds and anthraquinones were predominant in the chemical profile of the extract, which presented different levels of allelopathic effect on seed germination and seedling growth of plants both in germination chamber and in greenhouse, indicating strong allelopathic activity associated with the different compounds found in the leaves. Therefore, the results showed germination and growth inhibition at different levels, indicating that the substances contained in the leaves of Anacardium humile may be a promising alternative for the control of invasive species.
\end{abstract}

KEYWORDS: Allelopathy. Anacardium humile. Natural herbicides. Phenolic lipids.

\section{INTRODUCTION}

Allelopathy is a form of chemical interference among plants mediated by secondary metabolites, which are biochemically diverse molecules capable of acting in physiological processes. Although the first report on this interaction addressing losses in agricultural productivity (CHOU, 2006) dates from 300 B.C., in Brazil, applicability of these compounds in agroecosystems began only recently (REIGOSA et al., 2013).

According to Chou (2006), allelopathic compounds can be associated with synthetic herbicides, or even replace them, in the control of undesirable plants, reducing losses caused by decreased crop productivity. There is growing interest in new forms of management aimed at increasing control options and reducing costs and environmental contamination, and in this context allelopathy has gained space as an alternative.

Thus, searches for new species with potential use have been conducted, especially among those that have previously demonstrated chemical action, such as Anacardium humile St. Hill., commonly known as cajuzinho-do-cerrado. This species is used in popular medicine in regions of the Brazilian Cerrado, such as in Mato Grosso do Sul state, and studies have demonstrated that the aqueous extract of its leaves presents insecticide potential against the whitefly [Bemisia tuberculata (Bondar, 1923)] (ANDRADE FILHO et al., 2010), 
as well as other actions, such as anthelmintic activity (NERY et al., 2010) and hypoglycemic effect (URZÊDA et al., 2013).

Several studies have been conducted on the cultivation, propagation and tissue culture of $A$. humile (PINHAL et al., 2011; RESSEL et al., 2015; SANTOS \& SANTOS, 2015) not only because of these characteristics, but also because its fruits are valued by the biome populations. Accordingly, it is justified to investigate the herbicidal or growth phytoregulating potential of this species in order to understand its allelopathic interactions in cropping systems. Target species such as Lactuca sativa L. (lettuce) and Lycopersicon esculentum Mill. (tomato) have been used to assess the effect of allelopathic compounds because of their rapid germination and uniform growth, as well as weed species such as Senna obtusifolia (L.) Irwin \& Barneby (sicklepod), a species difficult to control that is becoming resistant to herbicides, forming dense infestations in the southeast region of the United States and in western Mato Grosso do Sul state, Brazil (SIMONI et al., 2006).

Thus, studies carried out in laboratory and greenhouse have tested extracts of A. humile as chemical agents, and have indicated the presence of new molecules that could be manipulated by the industry and produce new compounds with herbicide effect (SILVA et al., 2014).

Therefore, the present study aimed to determine the chemical profile and evaluate the herbicide potential of Anacardium humile leaves on the seed germination and seedling growth of Lactuca sativa (lettuce), Lycopersicon esculentum (tomato) and Senna obtusifolia (SICKLEPOD), both in vitro and in greenhouse.

\section{MATERIAL AND METHODS}

\section{Collection and preparation of material}

A. humile leaves were obtained from 20 matrices of Cerrado fragments $\left(20^{\circ} 26^{\prime} 21^{\prime \prime} \mathrm{S}\right.$; $\left.54^{\circ} 32 ' 27^{\prime \prime} \mathrm{W}\right)$ located in the municipality of Campo Grande, Mato Grosso do Sul state, Brazil. After collection, the samples were transported to the Laboratory of Research in Environmental Systems and Biodiversity, Agrarian Campus, University Anhanguera-Uniderp, where they were dried on countertop at room temperature $\left(27 \pm 2{ }^{\circ} \mathrm{C}\right)$ for $72 \mathrm{~h}$ and then fragmented and crushed in industrial mill. A voucher specimen was deposited at the herbarium of the aforementioned Institution under no. 8448.

\section{Preparation of aqueous extract}

The extract was prepared using $200 \mathrm{~g}$ of material (leaf powder) to $1000 \mathrm{~mL}$ of distilled water $\left(200 \mathrm{mg} \mathrm{mL}^{-1}\right.$ ), and remained under refrigeration for $24 \mathrm{~h}$. Subsequently, the mixture was subjected to ultrasonic bath for $30 \mathrm{~min}$, filtration, and static maceration for $24 \mathrm{~h}$; this procedure was repeated for seven days (OLIVEIRA et al., 2011). After solvent evaporation to dryness at low temperature $\left(<50{ }^{\circ} \mathrm{C}\right)$ on a rotary evaporator, $12.78 \mathrm{~g}$ of extract were obtained.

\section{Phytochemical analysis}

A qualitative chemical profile of the aqueous extract was obtained (MATOS, 2009; FONTOURA et al., 2015), with confirmation of the chemical groups in $\mathrm{UV}_{\text {visible }}$ spectrum. The chemical profile included determination of total phenolic and flavonoid contents (DO et al., 2014), pH, electrical conductivity, and soluble solids concentration.

\section{Bioassays in germination chamber - Germination and Growth}

The germination chamber tests were performed under the temperatures of $20{ }^{\circ} \mathrm{C}$ for lettuce seeds and $25{ }^{\circ} \mathrm{C}$ for sicklepod and tomato seeds. Five (5) $\mathrm{mL}$ (seed germination) and $10 \mathrm{~mL}$ (seedling growth) of the extract were poured at the concentrations of $25,50,100,150$ and $200 \mathrm{mg} \mathrm{mL}^{-1}$ for lettuce and tomatoes and of 100 and $200 \mathrm{mg} \mathrm{mL}^{-}$ ${ }^{1}$ for sicklepod, in addition to the control (distilled water), on two sheets of germitest paper. A smaller number of sicklepod seeds were used due to the difficulty in obtaining quality seeds of this species. In germination, Petri dishes ( $7 \mathrm{~cm}$ in diameter) were used with four replications of 25 seeds. Counting was performed every $24 \mathrm{~h}$ for 7 days, and the germination percentage and vigor of the seeds (MGT - mean germination time in days and GSI germination speed index) were assessed. In growth, transparent plastic boxes $(11 \times 3.5 \mathrm{~cm}$ in height) were used with four replications of 10 pre-germinated seeds, and the seedlings were evaluated after 10 days. The procedures were based on Rizzi et al. (2016).

\section{Bioassays in greenhouse}

The substrates were prepared using $950 \mathrm{~g}$ of vermiculite and $50 \mathrm{~g}$ of $A$. humile leaf powder: (950/50) (5\%), 900/100 (10\%) and 800/200 (20\%), in addition to a control (100\% vermiculite). After homogenization, they were moistened using distilled water and distributed in polystyrene trays with 128 cells. Sowing was performed using 100 seeds of each target species, and the emergence process was 
followed daily for 10 days; at the end, the seedlings were collected and measured.

\section{Experimental design and statistical analysis}

A completely randomized experimental design was used, and the data on germination and growth were submitted to analysis of variance (ANOVA); when significance was observed, the means were compared using the Tukey test at 5\% probability level.

\section{RESULTS AND DISCUSSION}

PEREIRA, K. C. L. et al.

\section{Phytochemical analysis}

The A. humile aqueous extract obtained showed different classes of secondary metabolites with predominance of anthraquinones and phenolic compounds (100\% intensity) and their derivatives, flavonoids, tannins and saponins, all with 50\% intensity, followed by reducing sugars, cardioactive heterosides and triterpenes ( $25 \%$ intensity), and with less intensity $(10 \%)$, steroids (Figure 1). Determination of total phenolic and flavonoid contents showed values of $229.0 \pm 0.12$ and 151.0 $\pm 0.5 \mathrm{mg} \mathrm{g}^{-1}$, respectively.

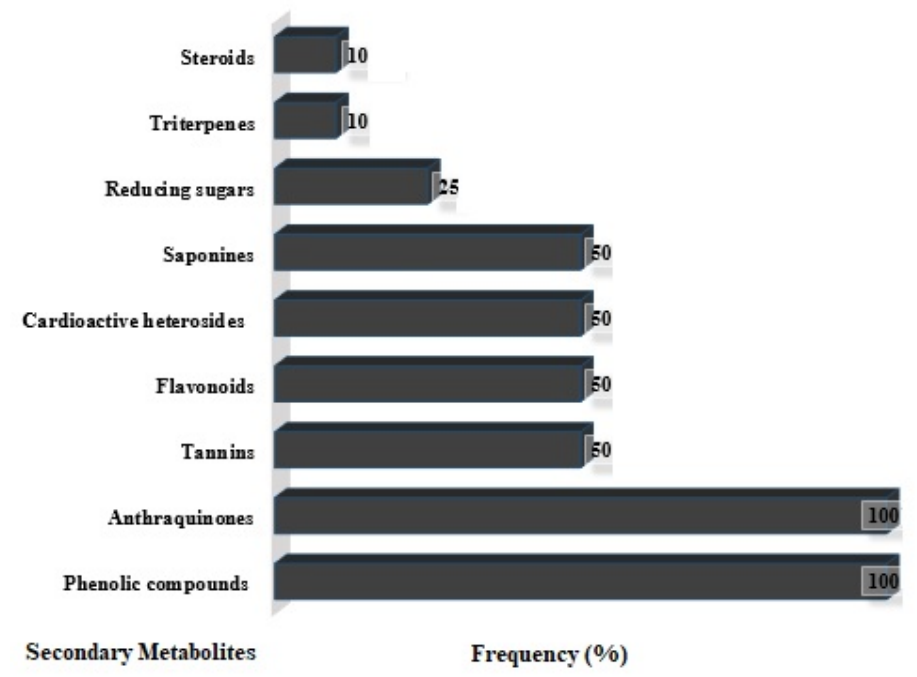

Figure 1. Classes and frequency (\%) of secondary metabolites found in Anacardium humile leaf aqueous extract from Cerrado fragments in Campo Grande, Mato Grosso do Sul state. Intensity levels: 10\% (low), 25\% (partially moderate), 50\% (moderate) and 100\% (high).

Spectrophotometric analyses in the UVvisible region (Figure 2) confirmed the phytochemistry results. The absorption band observed at $240 \mathrm{~nm}(\lambda \max \cdot \mathrm{MeOH})$ may be associated with triterpenes previously isolated from $A$. humile leaves by Matias et al. (2013). Bands were also observed at 280 and $360 \mathrm{~nm}$, with characteristics for phenolic and flavonoid compounds, respectively. Specifically, the absorption band at $330 \mathrm{~nm}$ can be associated with anacardic acids, a phenolic lipid common to genus Anacardium (MATIAS et al., 2017); whereas the band observed at $480 \mathrm{~nm}$ is common to anthraquinones (SILVERSTEIN et al., 2014).

The metabolites found are among the classes responsible for the allelopathic action due to their toxic effect on plant cells such as anthraquinones and triterpenes. Most of the compounds identified belong to the class of phenols and derivatives, which are assigned to present allelopathic activity, affecting cell elasticity and permeability, in addition to blocking mitochondrial respiration, thus inhibiting germination and negatively affecting the seedlings (FUJII; HIRADATE, 2007).

Particularly regarding the cardioactive heterosides, they are considered toxic and soluble in water - an important characteristic in the absorption and distribution of these molecules (RATES et al., 2017). The same can be assigned to the saponins, which present repellent and emulsifying action (ATHAYDE et al., 2017), interfering with germination due to interaction with cell membranes and altering their permeability, among other effects (FUJII; HIRADATE, 2007). 


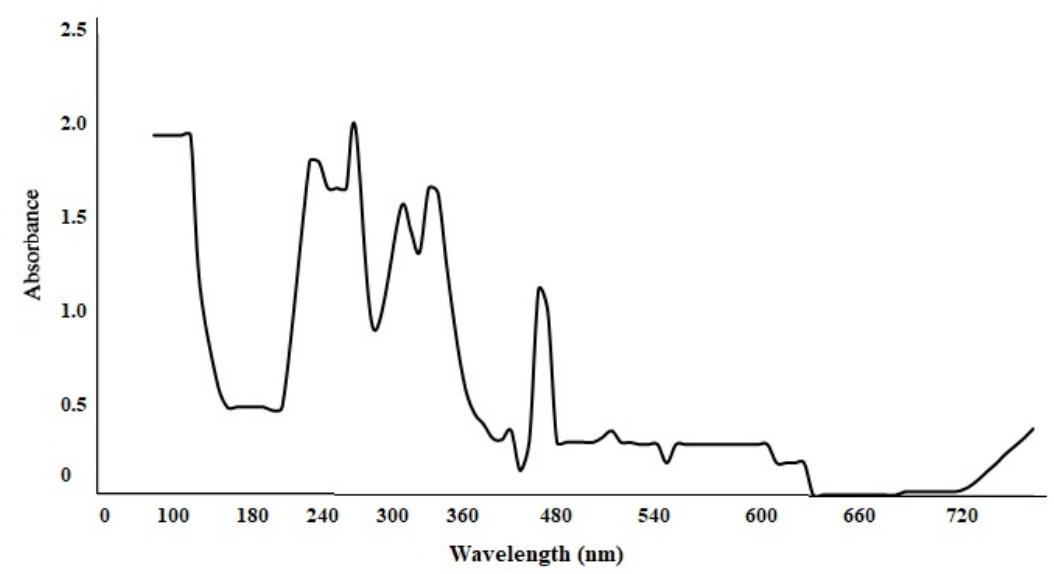

Figure 2. Absorption spectra in the UV-visible region of the Anacardium humile leaf aqueous extract from Cerrado fragments in Campo Grande, Mato Grosso do Sul state.

Steroids and terpenes present hormonal functions, and their presence may lead to an imbalance of the existing hormones and/or inhibition of their action, negatively affecting germination and growth and changing membrane permeability (FUJII; HIRADATE, 2007).

However, the extract composition varied compared with the results reported by Nery et al. (2010), who found presence of condensed tannins, flavonoids and alkaloids in the leaf aqueous extract of the species under study collected in the Cerrado of Minas Gerais state. The difference in metabolites probably stems from the fact that, in the plants, they are distributed in different organs and at different concentrations along their phenological phase (GOLDFARB et al., 2009). Plant origin region can also interfere, because the environment in which a plant grows can influence the presence or absence of certain substances, providing different results regarding the presence and/or intensity of compounds.

As for $\mathrm{pH}(5.0 \pm 0.02)$, the value found is suitable for germination and growth, because only high values of acidity and alkalinity can have a negative effect on these processes. Periotto et al. (2012) reported $\mathrm{pH}$ of 4.4 for leaves of the same species, a little more acid than the one found in this study. The conductivity value $\left(133 \pm 1.3 \mu \mathrm{S} \mathrm{cm} \mathrm{cm}^{-1}\right)$ may also be considered adequate, since values $<200$ $\mu \mathrm{Scm}^{-1}$ do not present deleterious effects. The conductivity values observed can be considered appropriate because, according to Souza et al. (1999), results $<200 \mu \mathrm{s} \mathrm{cm}^{-1}$ have no deleterious effects on seed germination and vigor. The concentration of soluble solids $(0.2 \pm 0.1)$, a way of estimating the osmotic potential, indicated that ${ }^{\circ}$ Brix tended to zero, showing low concentration of reducing sugars, and according to Oliveira et al.
(2013), small values do not affect solvent (water) absorption and the process of soaking the seeds.

\section{Germination bioassays}

The $A$. humile extract used did not interfere with the germination percentage of the sicklepod seeds, and negatively affected the lettuce seeds only at higher concentrations. Concerning the tomatoes, the effects were more pronounced, strongly affecting germination and causing seed death at higher concentrations. However, seed vigor of all species was negatively influenced, demonstrating that this extract has metabolites in its composition that negatively affect the germination process even in weeds, thus indicating its potential use (Table 1).

According to Ferreira and Aquila (2000) and Fujii and Hiradate (2007), typically, the allelopathic effect is greater on seedling growth than on seed germination. Periotto et al. (2012), in a study conducted with A. humile aqueous extract, verified that the germination of lettuce seeds was not affected by the different plant extract concentrations, whereas the GSI was negatively affected, corroborating the results found in this study. The tomato seeds showed higher sensitivity to the extract (Table 1), a factor probably associated with the family of this plant, Solanaceae, which would be more sensitive to the metabolites found; differently from lettuce, Asteraceae, in which the results would probably be associated with the species' physiological and biochemical processes, responding differently to the extract. Rizzi et al. (2016), testing different extracts of Vochysia haenkeana (Spreng.) Mart., also reported that tomato seeds were more affected than lettuce seeds, demonstrating their greater susceptibility to the metabolites, interfering with both seed germination and seedling growth. 
Table 1. Germination percentage (\%); vigor: germination speed index (GSI) and mean germination time (MGT) in days; seeds of lettuce, tomato and sicklepod; germination chamber, different extract concentrations $\left(\mathrm{mg} \mathrm{mL}^{-1}\right)$, Anacardium humile leaves

\begin{tabular}{cccccccccc}
\hline & \multicolumn{3}{c}{$\mathrm{G}(\%)$} & \multicolumn{3}{c}{ GSI } & \multicolumn{3}{c}{ MGT } \\
\cline { 2 - 9 } Extract & Lettuce & Tomato & Sicklepod & Lettuce & Tomato & Sicklepod & Lettuce & Tomato & Sicklepod \\
\hline 0 & $97 \mathrm{a}$ & $95 \mathrm{a}$ & $100 \mathrm{a}$ & $22.3 \mathrm{a}$ & $7.2 \mathrm{a}$ & $20.1 \mathrm{a}$ & $1.2 \mathrm{a}$ & $3.4 \mathrm{a}$ & $1.2 \mathrm{a}$ \\
25 & $93 \mathrm{a}$ & $93 \mathrm{a}$ & & $19.4 \mathrm{~b}$ & $5.7 \mathrm{~b}$ & & $1.5 \mathrm{a}$ & $4.2 \mathrm{~b}$ & \\
50 & $96 \mathrm{a}$ & $75 \mathrm{~b}$ & & $11.2 \mathrm{c}$ & $3.4 \mathrm{c}$ & & $2.2 \mathrm{~b}$ & $5.6 \mathrm{c}$ & \\
100 & $88 \mathrm{a}$ & $46 \mathrm{c}$ & $94 \mathrm{a}$ & $6.9 \mathrm{~d}$ & $1.9 \mathrm{~d}$ & $12.7 \mathrm{~b}$ & $3.4 \mathrm{c}$ & $6.2 \mathrm{~d}$ & $2.2 \mathrm{~b}$ \\
150 & $87 \mathrm{a}$ & $0 \mathrm{~d}$ & & $5.3 \mathrm{~d}$ & $0 \mathrm{e}$ & & $4.3 \mathrm{~d}$ & $0 \mathrm{e}$ & \\
200 & $62 \mathrm{~b}$ & $0 \mathrm{~d}$ & $100 \mathrm{a}$ & $3.3 \mathrm{e}$ & $0 \mathrm{e}$ & $10.1 \mathrm{~b}$ & $4.8 \mathrm{~d}$ & $0 \mathrm{e}$ & $2.7 \mathrm{~b}$ \\
\hline
\end{tabular}

* Means followed by the same lowercase letter in the column do not statistically differ among themselves (Tukey test, $5 \%$ probability).

The action potential of the aqueous extract of stem and leaves of $A$. humile has previously been reported by Periotto et al. (2012) and Pereira et al. (2018), who observed negative effects on the seed germination and seedling growth in lettuce and radish (Raphanus sativus L.), corroborating the findings of this study.

In conclusion, the use of $A$. humile leaf extract was effective, as it negatively interfere with the germination processes even in weeds - a factor probably associated with the solubility of certain compounds in water, such as saponins, tannins and flavonoids, in addition to the marked presence of anthraquinones, indicating the potential use of $A$. humile.

Despite the large number of studies addressing the allelopathic effects of plant extracts on seed germination and seedling growth, few have analyzed the correlation between presence of secondary metabolites and their intensity, seed germination and vigor, and seedling growth. Among these, the studies by Oliveira et al. (2011, 2013), Rizzi et al. (2016), Matias et al. $(2017,2018)$ and
Pereira et al. (2018) should be highlighted, as they confirm the results obtained in the present study, in which the presence of metabolites interfered in different ways with the germination and growth processes. The aforementioned authors verified that certain metabolites, such as phenolic compounds, flavonoids, cardioactive heterosides and saponins, are responsible for the allelopathic action observed, negatively affecting seed germination and seedling growth. Fujii and Hiradate (2007) reported that these compounds act in different ways, affecting cell elasticity and permeability, inhibiting germination and negatively affecting growth.

\section{Growth bioassays}

The A. humile extract used negatively influenced the development of the primary root and shoots of all species from the lowest concentrations, leading to death of lettuce seedlings at higher concentrations (Table 2), indicating that there is increased sensitivity in relation to the allelochemicals present.

Table 2. Roots and stems (mm) of lettuce, tomato and sicklepod seedlings; germination chamber; different extract concentrations $\left(\mathrm{mg} \mathrm{mL}^{-1}\right)$; leaves of Anacardium humile

\begin{tabular}{lllllll}
\hline \multirow{2}{*}{ Extract } & Lettuce & \multicolumn{3}{c}{ Tomato } & \multicolumn{2}{c}{ Sicklepod } \\
\cline { 2 - 7 } & Root & Stem & Root & Stem & Root & Stem \\
\hline 0 & $46.3 \mathrm{a}$ & $15.3 \mathrm{a}$ & $76.8 \mathrm{a}$ & $25.1 \mathrm{a}$ & $30.2 \mathrm{a}$ & $30.2 \mathrm{a}$ \\
25 & $34.2 \mathrm{~b}$ & $7.0 \mathrm{~b}$ & $41.8 \mathrm{~b}$ & $27.4 \mathrm{a}$ & & \\
50 & $4.5 \mathrm{c}$ & $7.6 \mathrm{~b}$ & $12.7 \mathrm{c}$ & $19.7 \mathrm{~b}$ & & \\
100 & $3.0 \mathrm{c}$ & $3.1 \mathrm{c}$ & $3.6 \mathrm{~d}$ & $10.3 \mathrm{c}$ & $8.7 \mathrm{~b}$ & $6.3 \mathrm{~b}$ \\
150 & $0 \mathrm{~d}$ & $0 \mathrm{~d}$ & $3.5 \mathrm{~d}$ & $7.3 \mathrm{de}$ & & \\
200 & $0 \mathrm{~d}$ & $0 \mathrm{~d}$ & $3.1 \mathrm{~d}$ & $5 \mathrm{e}$ & $7.5 \mathrm{~b}$ & $6.1 \mathrm{~b}$ \\
\hline
\end{tabular}

*Means followed by the same letter in the column do not differ statistically among themselves (Tukey test, $5 \%$ probability).

The results obtained were expected, with seedling development more affected than seed germination. Silva et al. (2014) reported similar findings in a study conducted with extracts of Caryocar coriaceum Wittm., with root and stem length suffering greater interference than germination. In contrast, Gusman et al. (2011) and Pereira et al. (2018) reported interference both with germination and initial growth, with the root being more affected at higher concentrations, a result similar to that found for Anacardium humile. Bulegon et al. (2015) verified that the extracts of 
ryegrass (Lolium multiflorum L.) and braquiaria (Brachiaria brizantha cv. Marandu) - two species of known allelopathic activity - did not show allelopathic effect on germination and enzyme activity of lettuce seedlings, results different from those found in this study; this situation is probably associated with the metabolites present and their concentrations, in addition to the location and time of collection of the plants.

However, unlike in the germination process, in growth, lettuce was the most affected species, and this factor is most likely associated with the fact that, during seedling development, changes occur in the biochemical and physiological pattern as well as in sensitivity to allelochemicals.

Once again, the findings indicate that the use of a simple solvent, water, was efficient in the extraction of metabolites, favoring growth inhibition with reduction in length of the structures, demonstrating the strong action of allelochemicals.

\section{Bioassays in greenhouse}

Table 3 shows that growth was differently affected in lettuce and tomato seedlings. Lettuce suffered more intensely the negative effects of the extract on emergence, ESI and size of seedlings from the lowest substrate concentration (5\%). In tomato, only the highest substrate concentration negatively affected emergence, and concentrations of 10 and $20 \%$ affected root growth, whereas ESI and stem size were benefited. As for sicklepod, the results indicated that there was interference with emergence, ESI and stem size; however, all seedlings of different treatments showed reduction in root length, demonstrating the effect of the metabolites on root growth. Normally, because this structure is in direct contact with the metabolites, it can suffer their action more intensely.

Table 3. Emergence (\%); emergence speed index (ESI); roots and stems (mm) of seedlings of lettuce (Let), tomato (Tom) and sicklepod (Sic); greenhouse; substrate with Anacardium humile leaf powder

\begin{tabular}{ccccccccccccc}
\hline & & $\%$ & & \multicolumn{3}{c}{ ESI } & \multicolumn{1}{c}{ Root } & \multicolumn{3}{c}{ Stem } \\
\hline & Let & Tom & Sick & Let & Tom & Sic & Let & Tom & Sic & Let & Tom & Sic \\
\hline 0 & 94 & 97 & 82 & 3.1 & 3.2 & 7.9 & 38.2 & 42.6 & 42.6 & 24.7 & 23.9 & 37.8 \\
& $\mathrm{a}$ & $\mathrm{a}$ & $\mathrm{a}$ & $\mathrm{a}$ & $\mathrm{b}$ & $\mathrm{A}$ & $\mathrm{a}$ & $\mathrm{a}$ & $\mathrm{a}$ & $\mathrm{a}$ & $\mathrm{b}$ & $\mathrm{a}$ \\
5 & 80 & 92 & 81 & 4.4 & 2.3 & 7.2 & 30.4 & 42.6 & 36.5 & 18.8 & 28.9 & 37.5 \\
& $\mathrm{~b}$ & $\mathrm{ab}$ & $\mathrm{a}$ & $\mathrm{b}$ & $\mathrm{a}$ & $\mathrm{A}$ & $\mathrm{b}$ & $\mathrm{a}$ & $\mathrm{b}$ & $\mathrm{b}$ & $\mathrm{a}$ & $\mathrm{a}$ \\
10 & 63 & 92 & 84 & 4.1 & 2.2 & 7.8 & 20.9 & 33.7 & 36.2 & 19.3 & 37.0 & 36.1 \\
& $\mathrm{c}$ & $\mathrm{ab}$ & $\mathrm{a}$ & $\mathrm{b}$ & $\mathrm{a}$ & $\mathrm{A}$ & $\mathrm{c}$ & $\mathrm{b}$ & $\mathrm{b}$ & $\mathrm{b}$ & $\mathrm{a}$ & $\mathrm{a}$ \\
20 & 50 & 84 & 82 & 5.0 & 2.3 & 7.7 & 7.9 & 24.1 & 35.4 & 12.3 & 30.9 & 36.9 \\
& $\mathrm{c}$ & $\mathrm{b}$ & $\mathrm{a}$ & $\mathrm{c}$ & $\mathrm{a}$ & $\mathrm{A}$ & $\mathrm{d}$ & $\mathrm{c}$ & $\mathrm{b}$ & $\mathrm{c}$ & $\mathrm{a}$ & $\mathrm{a}$ \\
\hline
\end{tabular}

*Means followed by the same letter in the column do not differ statistically among themselves (Tukey test, $5 \%$ probability).

The results again confirm the allelopathic action of the extract, with greater effect on lettuce, similarly to that observed in germination chamber (Table 2). However, the effect was lower than that observed in vitro, where the highest concentrations led to seedling death. In order to occur interference of compounds, these substances need to be released; however, this process is more complex under changing environmental conditions and presence of ultraviolet and infrared radiation, which can change the structure of the allelochemicals, in addition to the degradation by microorganisms; this situation can justify the results obtained with tomato, in which the extract action occurred from the lowest concentrations in germination chamber and at the highest concentration in greenhouse. Concerning lettuce, the opposite was observed, with germination being affected only at the highest concentration in germination chamber and at the lowest concentration in greenhouse. These findings are similar to those reported by Pereira et al. (2018) in a study conducted with extracts of the same species.

According to Almeida et al. (2008), when in the environment, the allelopathic compounds may suffer or cause oxidative stress, acting directly in cell degradation, impairing the physiological processes and affecting the initial development of seedlings; in contrast, in certain situations, cell degradation may lead to the production of molecules that foster faster growth, as observed for tomato shoots in greenhouse.

\section{CONCLUSIONS}

There was reduction in seed germination and seedling growth at different levels, indicating that the substances contained in the leaves of Anacardium humile may be a promising alternative for the control of invasive species. 
The allelopathic action is most likely associated with the high intensity of phenolic compounds and anthraquinones.

\section{ACKNOWLEDGMENTS}

The authors are grateful to CAPES, for the master's and doctoral scholarships, and to CNPq, for the scholarships in productivity in research (PQ2) and undergraduate studies (PIBIC). We also would like to thank CNPq, CPP, INAU, FUNDECT and Uniderp University for funding the Interdisciplinary Research (GIP) and Natural Products (PN) Group.

RESUMO: O gênero Anacardium, Anacardiaceae, destaca-se pela presença de compostos fenólicos. Uma de suas espécies, investigada pelos diferentes potenciais de uso, é Anacardium humile. No entanto, pouco se sabe sobre seus efeitos alelopáticos. Portanto, o presente trabalho objetivou determinar o perfil químico e avaliar o potencial herbicida de suas folhas sobre a germinação e crescimento de Lactuca sativa (alface), Lycopersicon esculentum (tomate) e Senna obtusifolia (fedegoso) in vitro e em casa de vegetação. Folhas de $A$. humile foram obtidas de 20 matrizes de Cerrado, município de Campo Grande/MS, Brasil. Uma espécime foi depositada no herbário (N. 8448). O extrato aquoso foi obtido das folhas secas e trituradas e o método de extração foi banho de ultrassom (30 minutos) seguido de maceração estática, sendo o solvente evaporado e $12,78 \mathrm{~g}$ de extrato obtido. O extrato foi submetido ao perfil químico e determinado: teor de fenóis totais e flavonóides, $\mathrm{pH}$, condutividade elétrica e concentração de sólidos solúveis. Para os bioensaios in vitro, o extrato foi utilizado em diferentes concentrações $\left(25,50,100,150\right.$ e $\left.200 \mathrm{mg} \mathrm{mL}^{-1}\right)$. Em casa de vegetação, os substratos foram preparados com $950 \mathrm{~g}$ do substrato vermiculita e $50 \mathrm{~g}$ do pó das folhas de A. humile (950/50) (5\%); 900/100 (10\%); 800/200 (20\%), além do controle, 100\% vermiculita, com delineamento experimental inteiramente casualizado. $\mathrm{O}$ extrato apresentou como perfil químico predominante os compostos fenólicos e antraquinonas, com efeito alelopático sobre a germinação e crescimento em câmara de germinação e estufa, em diferentes graus, indicando que há uma forte atividade alelopática associada aos diferentes compostos encontrados nas folhas. Portanto, os resultados indicaram germinação e inibição do crescimento, em diferentes níveis, demonstrando que as substâncias contidas nas folhas de $A$. humile podem ser uma alternativa promissora para o controle de espécies invasoras.

PALAVRAS-CHAVE: Alelopatia. Anacardium humile. Herbicidas naturais. Lipídios fenólicos.

\section{REFERENCES}

ALMEIDA, G. D.; ZUCOLOTO, M.; ZETUN, M. C.; COELHO, I.; SOBREIR, F. M. Estresse oxidativo em células vegetais mediante aleloquímicos. Revista Facultad Nacional de Agronomía, Medellín, v. 61, n. 1, p. 4237-4247, 2008.

ANDRADE FILHO, N. N.; ROEL, A. R.; PORTO, K. R. D. A.; SOUZA, R. O.; COELHO, R. M.; PORTELA, A. Toxicidade do extrato aquoso das folhas de Anacardium humile para Bemisia tuberculata. Ciência Rural, Santa Maria, v. 40, n. 8, p. 1689-1694, 2010. Disponível em: http://dx.doi.org/10.1590/S010384782010005000125 .

RESSEL, K. A.; SOUZA LIMA-RIBEIRO, M.; DOS REIS, E. F. Desempenho de progênies de diferentes matrizes de cajuzinho-do-cerrado mediante o armazenamento e o peso das núculas. Ciência Rural, Santa Maria, v. 45, n. 10, p.1782-1787, 2015. Disponível em: http://dx.doi.org/10.1590/0103-8478cr20141143.

ATHAYDE, M. L.; TAKETA, A. T. C.; GOSMANN, G. G.; SCHENKEL, E. P. Saponinas. In: SIMÕES, C. M. O.; SCHENKEL, E. P.; MELLO, J. C. P. de; MENTZ, L. A.; PETROVICK, P. R. Farmacognosia: do produto natural ao medicamento. Porto Alegre: Artmed, 2017. cap.19. p. 285-302. 
BULEGON, L. G.; MEINERZ, C. C.; CASTAGNARA, D. D.; BATTISTUS, A. G.; GUIMARÃES, V. F.; NERES, M. A. Alelopatia de espécies forrageiras sobre a germinação e atividade de peroxidase em alface. Scientia Agraria Paranaensis, Marechal Cândido Rondon, v. 14, n. 2, p. 94-99, 2015. http://dx.doi.org/ 10.18188/1983-1471/sap.v14n2p94 -99.

CHOU, C. H. Introduction to allelopathy. In: REIGOSA, M. J.; PEDROL, N.; GONZÁLEZ, L. Allelopathy: a physiological process with ecological implications. Dordrecht: Springer, 2006. p.1 -9.

DO, Q. D.; ANGKAWIJAYA, A. E.; TRAN-NGUYEN, P. L.; HUYNH, L. H.; SOETAREDJO, F. E.; ISMADJI, S.; JU, Y. H. Effect of extraction solvent on total phenol content, total flavonoid content, and antioxidant activity of Limnophila aromatica. Journal of Food and Drug Analysis, China, v. 22, p.296-302, 2014. Disponível em: http://dx.doi.org/10.1016/j.jfda.2013.11.001.

FERREIRA, A. G.; AQUILA, M. E. A. Alelopatia: uma área emergente da ecofisiologia. Revista Brasileira de Fisiologia Vegetal, Campinas, v. 12, p.175-204, 2000.

FONTOURA, F. M.; MATIAS, R.; LUDWIG, J.; OLIVEIRA, A. K. M. D.; BONO, J. A. M.; MARTINS, P. D. F. R. B.; GUEDES, N. M. R. Seasonal effects and antifungal activity from bark chemical constituents of Sterculia apetala (Malvaceae) at Pantanal of Miranda, Mato Grosso do Sul, Brazil. Acta Amazonica, Manaus, v. 45, p. 283-292, 2015. http://dx.doi.org/10.1590/1809-4392201500011.

FUJII, Y.; HIRADATE, S. Allelopathy: new concepts \& methodology. Enfield: Science Publishers, 2007. 398 p.

GOLDFARB, M.; PIMENTEL, L. W.; PIMENTEL, N. W. Alelopatia: relações nos agroecossistemas. Tecnologia \& Ciência Agropecuária, Paraíba, v. 3, n. 1, p. 23-28, 2009.

GUSMAN, G. S.; YAMAGUSHI, M. Q.; VESTENA, S. Potencial alelopático de extratos aquosos de Bidens pilosa L., Cyperus rotundus L. e Euphorbia heterophylla L. Iheringia Série Botânica, Porto Alegre, v. 66, n. 1, p. 87-98, 2011.

MATIAS, R.; ROEL, A. R.; ANDRADE FILHO, N. N.; SCHLEDER, E. E.; YASUNAKA, D. S.; CARDOSO, C. A. Control of silverleaf whitefly in cassava grown in the greenhouse treated with Anacardium humile (Anacardiaceae) extract. Bioscience Journal, Uberlândia, v. 29, n. 6, p.1815-1822, 2013.

MATIAS, R.; ROSA, A. C.; OLIVEIRA, A. K. M.; PEREIRA, K. C. L.; RIZZI, E. S.; MACHADO, A. A. Cashew nut shell liquid and formulation: toxicity during the germination of lettuce, tomato seeds and Coffee senna and seedling formation. Acta Scientiarum. Agronomy, Maringá, v. 39, n. 4, p. 487-495, 2017. http://dx.doi.org/10.4025/actasciagron.v39i4.32603.

MATIAS, R.; PEREIRA, K. C. L.; RIZZI, E. S. R.; ABREU, C. A. A.; ROSA, A. C.; OLIVEIRA, A. K. M. Potencial alelopático das folhas de Pouteria ramiflora (Mart.) Radlk. na germinação e desenvolvimento inicial de Lactuca sativa L. e Solanum lycopersicum L. Gaia Scientia, João Pessoa, v. 12, n. 3, p. 168-180, 2018. https://doi.org/10.22478/ufpb.1981-1268.2018v12n3.39399

MATOS, J. F. A. Introdução a fitoquímica experimental. 2. ed. Fortaleza: UFC, 2009. 150p.

NERY, P. S.; NOGUEIRA, F. A.; MARTINS, E. R.; DUARTE, E. R. Effects of Anacardium humile leaf extracts on the development of gastrointestinal nematode larvae of sheep. Veterinary Parasitology, USA, v. 171, n. 3, p.361-364, 2010. http://dx.doi.org/10.1016/j.vetpar.2010.03.043.

OLIVEIRA, A, K. M.; RIBEIRO, J. W. F.; FONTOURA, F. M.; MATIAS, R. Leaf extract effects of Vochysia divergens on lettuce and tomato. Allelopathy Journal, Haryana, v. 31, n. 1, p. 129-138, 2013. 
OLIVEIRA, A. K. M.; RIBEIRO, J. W. F.; MATIAS, R.; GUSMÃO, D. D. H.; PEREIRA, K. C. L. Potencial alelopático de folhas frescas de bacupari (Rheedia brasiliensis (Mart.) Planch. \& Triana) na germinação de alface. Revista Brasileira de Biociências, Porto Alegre, v. 9, n. 4, p. 550-553, 2011.

PEREIRA, K. C. L.; OLIVEIRA, A. K. M.; MATIAS, R.; RIZZI, E. S. R.; ROSA, A. C. Potencial alelopático do extrato etanólico de Anacardium humile (cajuzinho-do-cerrado) na germinação e formação de plântulas de alface, tomate e fedegoso. Gaia Scientia, João Pessoa, v. 12, n. 2, p. 144-160, 2018. https://doi.org/10.22478/ufpb.1981-1268.2018v12n2.37091

PERIOTTO, F.; GUALTIERI, S. C. J.; LIMA, M. I. S. Allelopathic potential of Anacardium humile Mart. and their effects on seed germination and early development of seedlings. Revista Eletrônica Científica Inovação e Tecnologia, Curitiba, v. 2, n. 6, p.2-14, 2012.

PINHAL, H. F.; ANASTÁCIO, M. R.; CARNEIRO, P. A. P.; SILVA, V. J.; MORAIS, T. P.; LUZ, J. M. Q. Aplicações da cultura de tecidos vegetais em fruteiras do Cerrado. Ciência Rural, Santa Maria, v. 41, n. 7, p. 1136-1142, 2011. http://dx.doi.org/10.1590/S0103-84782011005000089.

RATES, S. M. K.; BRIDI, R.; BRAGA, F. C.; SIMKÕES, C. M. O. Heterosídeos cardioativos. In: SIMÕES, C. M. O.; SCHENKEL, E. P.; MELLO, J. C. P. de; MENTZ, L. A.; PETROVICK, P. R. Farmacognosia: do produto natural ao medicamento. Porto Alegre: Artmed, 2017. p. 272-284.

REIGOSA, M.; GOMES, A. S.; FERREIRA, A. G.; BORGHETTI, F. Allelopathic research in Brazil. Acta Botanica Brasilica, Feira de Santana, v. 27, n. 4, p. 629-646, 2013. http://dx.doi.org/10.1590/S010233062013000400001.

RIZZI, E. S.; PEREIRA, K. C. L.; ARAUJO ABREU, C. A.; LIMA SILVA, B. C. F.; FERNANDES, R. M.; OLIVEIRA, A. K. M.; MATIAS, R. Allelopathic potential and phytochemistry of cambarazinho (Vochysia haenkeana (Spreng.) Mart.) leaves in the germination and development of lettuce and tomato. Bioscience Journal, Uberlândia, v. 32, n. 1, p.98-107, 2016. http://dx.doi.org/10.14393/BJ-v32n1a2016-29614.

SANTOS, R. C.; SANTOS Júnior, J. E. Divergência genética por análise multivariada de caracteres fenotípicos de Anacardium humile (St. Hilaire). Ceres, Viçosa, v. 62, n. 6, p. 553-560, 2015. https://doi.org/10.1590/0034737X201562060007

SILVA, M. A. P.; MEDEIROS Filho, S.; DUARTE, A. E.; MOREIRA, F. J. C. Potencial alelopático de Caryocar coriaceum Wittm na germinação e crescimento inicial de plântulas de alface. Caderno Cultura Ciência, Cariri, v. 13, p.17-24, 2014. http://dx.doi.org/10.14295/cad.cult.cienc.v13i1.819.

SILVERSTEIN, R. M.; WEBSTER, F. X.; KIEMLE, D. J.; DAVID L. B. Spectrometric identification of organic compounds $8^{\text {th }}$ edition. New Jersey: Jonh Wiley \& Sons, Inc., 2014. 464p.

SIMONI, F.; PITELLI, R. L. C. M.; PITELLI, R. A. Efeito da incorporação no solo de sementes de fedegoso (Senna obtusifolia) colonizadas por Alternaria cassiae no controle desta planta infestante. Summa Phytopathologica, Botucatu, v. 32, n. 4, p. 367-372, 2006. https://doi.org/10.1590/S0100-54052006000400008

SOUZA, C. L. M.; MORAIS, V.; SILVA, E. R.; LOPES, H. M.; TOZANI, R.; PARRAGA, M. S.;

CARVALHO, G. J. A. Efeito inibidor dos extratos hidroalcóolicos de coberturas mortas sobre a germinação de sementes de cenoura e alface. Planta Daninha, Viçosa, v. 17, n. 2, p. 263-271, 1999.

https://doi.org/10.1590/S0100-83581999000200010

URZÊDA, M. A.; MARCUSSI, S.; SILVA PEREIRA, L. L.; FRANÇA, S. C.; PEREIRA, A. M. S.; PEREIRA, P. S.; SOARES, A. M. Evaluation of the hypoglycemic properties of Anacardium humile aqueous extract. Evidence-Based Complementary and Alternative Medicine, California, v. 2013, p.1-8, 2013. http://dx.doi.org/10.1155/2013/191080. 